\title{
A discursive institutionalist approach to American foreign policy - principled and cognitive interpretations of Bosnia
}

\author{
Morgan Thomas Rees \\ School of Government and International Relations, Griffith University, Brisbane, Australia
}

\begin{abstract}
The disintegration of Yugoslavia in 1991 was a pivotal challenge in U.S. foreign policy during the early 1990s. Specifically, ethnic cleansing in Bosnia proved to be a particularly contentious issue across two presidential administrations. Even as both Presidents Bush and Clinton recognised the humanitarian atrocities - initially, neither was willing to use military force in response, fearing any U.S. intervention would lead to a Vietnam-like quagmire. Yet, following the massacre at Srebrenica in 1995, Clinton's position changed, favouring decisive action. Given that during this time, the U.S. remained a great power and enjoyed relative stability in coalitional arrangements - what explains this variation in policy? To explain this variation, I build on discursive institutionalist approaches, which distinguish between different types of ideas, offering two mechanisms - normative displacement and cognitive repression - by which agents come to interpret interests in more principled, or cognitively-laden ways, leading to variation absent systemic or ideational shifts.
\end{abstract}

\section{KEYWORDS}

Discursive institutionalism; International Relations Theory; American foreign policy; Bosnia; ideas

\section{Introduction}

In the years that followed the end of the Cold War, the disintegration of the former Yugoslavia and subsequent ethnic cleansing of Bosnian Muslims would prove to be one of the biggest challenges to US foreign policy in the post-Cold War world. Across two presidential administrations - the Bosnia question would yield the same non-committed attitude. Even as the George Bush administration would recognise the humanitarian situation as dire, they argued that there was no way of assisting in line with US foreign policy interests. Bosnia would be cast as a 'problem for Europe' with James Baker, the White House Chief of Staff, noting that the United States 'did not have a dog in the fight' (Baker quoted in Power, 2003, p. 267). The Clinton administration would adopt a similar position fearing that intervention in the Balkans would lead to quagmire. Even as the conflict drew on and the Clinton administration came to see Bosnia as 'a cancer' (Woodward, 1996, p. 253) on US foreign policy - it was not until the massacre at Srebrenica in July 1995 that US policy would shift from this position of restraint to one willing to employ military force. In the months that followed, the US - in conjunction with NATO - would commence 
an aerial campaign bringing an end to the Bosnian War in December 1995. But what explains this variation? From 1991 to 1995 - two presidential administrations maintained a policy of restraint toward the Bosnia conflict. What caused this variation in policy given that during this time, the US remained a great power and enjoyed relative stability in coalitional alignments?

Existing realist (Dueck, 1996; Schweller, 1998; Waltz, 1979), constructivist (Blyth, 2001; Finnemore \& Sikkink, 1998) and historical institutionalist (Capoccia \& Kelemen, 2007; Mahoney \& Thelen, 2010; Pierson, 2004) approaches typically rely on exogenous shocks to the material or ideational foundations of state interests to bring about change, and equally assume implicitly that agents interpret information efficiently. However, such approaches to foreign policy decision-making, which focus on simple cost-benefit equations, interest-based logics, or logics of appropriateness, are limiting. Foreign policy decision-making is an iterative process. A given set of conditions does not necessarily mean agents will pursue preconceived interests they have formulated. Instead, interests are constantly interpreted and reinterpreted in different ways, even in the absence of exogenous shocks. Foreign policy decision-making is a complex process involving many actors with different sets of experiences, beliefs, and values. Each of these agents bring a different set of ideas, stories and preferences which gain power at different points in time. To better understand this iterative process of foreign policy decision-making, I argue that agents interpret interests to varying degrees through cognitive or principled types of ideas. To trace this variation, I offer an original theoretical framework built on Vivien Schmidt's discursive institutionalist (Carstensen \& Schmidt, 2016; Schmidt, 2006, 2008, 2010, 2014) distinction between different types and forms of ideas (Schmidt, 2008, pp. 306-309). In doing so, I demonstrate how agents use different types of ideas as 'weapons' (Blyth, 2002, pp. 39-40) where tensions emerge between principled and cognitive interpretations. The consequence of this leads to variation in foreign policy decisionmaking as ideas are cognitively repressed, or normatively displaced as information (Schmidt, 2008, pp. 306-309) comes in different forms. As such, by applying this discursive institutionalist framework to the Bosnian crisis, it is possible to identify the interpretive shifts that led to variation in policy between 1992 and 1995.

This article is divided into three sections. First, I make a case that discursive institutionalist approaches can provide important insights into the study of security-based areas of IR that have been overlooked by rationalist approaches. Specifically, adopting a discursive institutionalist approach which examines the content of ideas allows for greater analysis of endogenous institutional sources of variation in state interests. The second section sets out a framework for understanding the content of ideas and interactive discourse surrounding the Bosnia crisis. To highlight how agents come to rely on different types of ideas in their interpretation of state interests, I advance two mechanisms by which these ideas principled and cognitive - come to the fore ${ }^{1}$; normative displacement (Mahoney \& Thelen, 2010) and cognitive repression. ${ }^{2}$ Finally, I provide a brief overview of the Bosnia crisis from the US perspective - focussing on agents' discursive interactions in the process of advancing the US's Bosnia policy. In the Bush administration - I argue that these discursive interactions centred on technocratic efforts to maintain the balance of power, and institutional preferences to avoid quagmire as the Bosnia conflict was likened to Vietnam and ultimately deemed to fall outside of US vital security interests. These efforts would yield a cognitive repression as principled sources of information were repressed by more cognitively- 
laden ideas. This repression of principled information would carry through the early years of the Clinton administration until the massacre at Srebrenica in 1995 which would see normative displacement alter interpretations of interests as more principled types of ideas gained traction with ideas coming in the form of images of atrocity - leading to intervention.

\section{Rationalist and constructivist limits - overrated interpretive efficiency}

Throughout the literature on International Relations, scholars have provided numerous explanations regarding the formation of foreign policy and state interests. Even as realists and constructivist scholars disagree with respect to the importance of material or ideational structures, both suggest that these structures are self-reinforcing and that agents are capable of adjusting when these structures shift (Gilpin, 1981, p. 46). Realist perspectives, for instance, see interests defined in terms of 'power' (Morgenthau, 1948, p. 5). As such, they argue that states will seek balance of power arrangements, shifting with the rise and fall of great powers (Kissinger, 1994; Waltz, 1979, p. 128). In doing so, however, they assume that the balance of power is self-evident. Neoclassical realists have been slightly more restrained in their emphasis on systemic pressures, acknowledging that social factors influence the decision-making process, arguing; 'Foreign policy choices are made by actual political leaders and elites, and so it is their perceptions of relative power that matter, not simply relative quantities of physical resources or forces in being' (Rose, 1998, pp. 146-147; see also Dueck, 1996; Schweller, 1998). Yet, there is a belief that inefficient choices simply cancel out over time without providing an explanation as to how such 'inefficient' decisions are made. From these realist perspectives, shifts in US foreign policy broadly follow shifts in the balance of power and the rise and fall of great powers such as the demise of the Soviet Union or the rise of China.

Similarly, constructivists, emphasising the role of social conventions, assume agents typically intellectuals - construct 'worlds they know' (Onuf, 1989, p. 38) and that ideas 'reduce uncertainty' (Blyth, 2001, p. 3, 2002, p. 35; see also, Finnemore \& Sikkink, 1998) acting to stabilise interests, defined as 'beliefs about how to meet needs' (Wendt, 1999, p. 130). Blyth (2002, pp. 9-10) broadly defines crises as events which bring about uncertainty, ${ }^{3}$ justifying a broad reinterpretation of the principled foundations of state interests. Similarly, Hay (1996, p. 255) suggests that crises are a 'process of transformation'. In this sense, constructivists share with realists a reliance on exogenous shocks to the foundational bases of state interests to explain change. Put differently, both realists and constructivists overrate the interpretive efficiency of agents, implicitly assuming that agents use information efficiently. Some, including Barnett and Finnemore (1999, p. 700) have recognised the potential for institutional rules to become inefficient and 'self-defeating'. Yet, even constructivist efforts retain rationalist (Fearon \& Wendt, 2002) assumptions regarding agents' capacity to construct worlds that they know. In doing so, they overlook 'interpretive ambiguities' (Widmaier, 2015, p. 7) that enable agents to give shared ideas evolving meaning as time goes by. As such, these approaches tend to see shifts in American foreign policy interests as emerging out of crises which give rise to new ideas and long term stability.

Whereas realist and constructivist approaches have typically pointed to exogenous shocks as the source of change in state interests, recent works in historical institutionalism 
(see Capoccia \& Kelemen, 2007; Fioretos, 2011; Pierson, 2004) recognise the potential for adjustment to state interests thanks to the ambiguity of institutional rules. To this end, Mahoney and Thelen (2010) put forth a theory of incremental change. In doing so, they argue 'rules can never be precise enough to cover the complexities of all possible realworld situations' (Mahoney \& Thelen, 2010, p. 11) leaving open the possibility of policy inconsistency. However, there remains two key issues with such an approach, which leaves the door open for discursive institutionalists. First, in advancing this approach, Mahoney and Thelen (2010) retain the assumption that agents use information efficiently in their pursuit of stabilising interests. Second, they assume that agents will seek to stabilise existing interests and institutions, thus, limiting their agency. While historical institutionalist theories have offered valuable contributions in terms of identifying the significance of punctuated moments, as well as the capacity for more incremental change, their approaches are limited in understanding the causal reasons for endogenous sources of institutional change. As such, for historical institutionalists, explaining variation in interests poses challenges given their emphasis on the stability of ideas. Stephen Bell has noted that such perspectives have underrated agency, himself recognising that institutional agents can either chose to pursue stasis or change (Bell, 2017, p. 727). Such an approach calls for a greater appreciation of the interpretive flexibility agents have to contest institutional constraints by looking at the psychological foundation of ideas. In doing so, Bell acknowledges the need to take seriously 'how agents understand and appraise this world' (Bell, 2017, p. 725).

Redressing this implied assumption made across these theoretical approaches - that agents use information efficiently - discursive institutionalists highlight how agents can interpret information in principled or cognitive ways (Schmidt, 2008, 2014). Discursive institutionalism has a broad scope in its capacity to analyse both the substantive content of ideas and the 'process of discourse in institutional context' (Schmidt, 2014, p. 190; see also Campbell \& Pedersen, 2010; Schmidt, 2008). They emphasise what Widmaier (2016, p. 12) describes as a 'value-distributional' approach which distinguishes between two types of socially constructed ideas (Schmidt, 2008, pp. 306-309). ${ }^{4}$ First, principled beliefs, which broadly outline 'what's right' (Widmaier, 2016, p. 15) and 'what one ought to do' (Schmidt, 2008, p. 306); second, causal ideas which provide the recipes or instructions on 'what is and what to do' (Schmidt, 2008, p. 306). Put differently, causal ideas also referred to as cognitive ideas - justify policies by 'speaking to their interest-based logic' (Schmidt, 2008, pp. 306-308), colloquially put by Widmaier (2016, p. 15) as 'what works'. Similarly, Carstensen and Schmidt (2016, p. 324) have highlighted a so-called 'power through ideas' outlining agents' capacity to persuade other actors to accept their views. In doing so, they recognise that the acceptance of a view may not represent the 'best' argument, rather the 'persuasiveness of an idea depends on both the cognitive and normative (principled) arguments that can be mustered in its support' (Carstensen \& Schmidt, 2016, p. 324).

In terms of agency, Schmidt $(2006,2008,2010)$ distinguishes between 'communicative' and 'coordinative' discourses. The former 'encompasses the wide range of political actors who bring the ideas developed in the context developed in the coordinative discourse' (Schmidt, 2010, p. 3). Such communicative discourses are often employed by the media, opposition groups, and public intellectuals who work to legitimise ideas to the broader public (Schmidt, 2008, p. 310). In this way, this discourse is often more principled as it 
speaks to appropriateness of policies. The latter, by contrast, generally consists of the policy 'elite' or 'epistemic communities' (Haas, 1992) who share ideas and policy access. Coordinative discourses typically consist of more refined cognitive ideas. Such insights provide scope for deeper analysis of variation in agents' interpretations of state interests, something which historical institutionalists - and other rationalist scholars - have struggled to account for.

Through these observations, discursive institutionalism provides important insights to help us better understand how agents make decisions to pursue stasis or change using these different types of ideas. Yet, while this emphasis on different types of ideas is important - discursive institutionalists have not done enough to show why, or how, agents shift between principled and cognitive interpretations. The issue remaining is how to demonstrate when agents come to rely on these different types of ideas. It is only by analysing these ideational tensions within presidential administrations that we can fully appreciate and understand sources of endogenous variation in state interests. In doing so, it is possible to provide a more comprehensive analysis how variation in foreign-policy decisionmaking occurs and shed new light on America's response to the 1990s Bosnia crisis given relative stability in material and coalitional alignments. In the following section, I outline a framework and two mechanisms to help better understand variation in US foreign policy interests by tracing the interplay between principled and cognitive interpretations.

\section{Framework and mechanisms}

To highlight the interplay between these different types of ideas, I advance a model to show how agents come to repress and displace different types of information in their effort to interpret foreign policy interests. I begin from the constructivist perspective that interests and events are socially constructed. Given this foundational starting point, I then integrate discursive institutionalist insights. This approach takes an important step to understand variation in foreign policy decision-making by moving beyond rationalist assumptions regarding agents' efficient use of information. It highlights how agents repress and displace interpretations of interests given shifting types of information. Importantly, I provide two mechanisms through which this variation in foreign policy decisionmaking may occur; normative displacement and cognitive repression.

First, where crises bring about uncertainty (Blyth, 2002, pp. 8-9) there is a need to interpret interests defined as 'beliefs about how to meet needs' (Wendt, 1999, p. 130). Under uncertainty, interests 'become something to be explained' (Blyth, 2002, p. 9). However, where Blyth acknowledges that ideas 'reduce uncertainty' (Blyth, 2002, p. 9), there is a need to highlight the type and form of ideas at play (Schmidt, 2008, pp. 306-309). Indeed, crises are surrounded by numerous narratives each pushing different sets of ideas. Schmidt distinguishes between principled ideas which play to the 'aspirations and ideas' and serve to 'legitimate policies in reference to their appropriateness', and cognitive types of ideas which provide 'recipes' and 'guidelines' for action - justifying policies 'by speaking to their interest-based logic' (Schmidt, 2008, pp. 306-307). These ideas make it possible for agents to develop a greater sense of interests by narrowing the scope of choice. Yet tensions between these different types of ideas emerge given that - as highlighted by Andrew Ross (2006, pp. 199-200) - principled beliefs tend to prefigure cognitive 
ideas as 'values are inspired and absorbed before being chosen' and act to 'tinge our intellectual beliefs'. In this way, principled ideas - of which agents may not be fully aware - may act to shape interests as agents react to uncertainty. Taking Blyth and Schmidt's notions together, ideas reduce uncertainty in either principled ways regarding what one 'ought to do', or more cognitive ways regarding 'what works' (Widmaier, 2016, p. 15).

Second, agents advance these ideas as 'weapons' (Blyth, 2002, pp. 39-40) during institutional struggles to instigate their particular interpretation of interests. Cognitive ideas advance preferences based on institutionalised, 'interest-based logics' (Schmidt, 2008, pp. 306-309) regarding 'what works' (Widmaier, 2016, p. 15). For instance, to the extent that the George Bush administration saw the conflict in the Balkans as primarily a balance of power issue in which the US had no material stake - arguments regarding the potential use of force would fall back to the Powell Doctrine. ${ }^{5}$ Yet, reliance on such institutionalised, coordinative approaches to foreign policy can see agents ignore more principled sources of information which may be necessary for the adaptation of state interests. I refer to such interpretations as cognitive repression as agents repress principled, communicative appeals, thus, ignoring information which may challenge existing institutional interpretations of state interests as they interpret preferences with an interestbased logic' (Schmidt, 2008, p. 307).

By contrast to the potential for repression of principled sources of information in more cognitive interpretations, principled types of ideas may yield a displacement of these more refined, cognitive interpretations where communicative appeals can no longer be ignored. I refer to the displacement of more cognitive interpretations as normative displacement. Normative displacement may see interests interpreted in more principled ways principled sources of information displace institutionalised interpretations. In such situations, interests are interpreted less in terms of 'interest-based logic' and more in terms of their appropriateness (March \& Olsen, 1998, p. 951) or 'what's right' (Widmaier, 2016, p. 15). For instance, following the massacre in Srebrenica in 1995, the Clinton administration's interpretations of US Bosnia policy would be displaced as images of dead and dying Bosnian Muslims propelled communicative appeals. The Bosnia crisis came to be viewed as a 'cancer' on US foreign policy (Woodward, 1996, p. 253), as parallels were drawn between Clinton's inaction and Neville Chamberlain's appeasement of Hitler. Even as the balance of power of arguments advanced by the Bush administration remained formally the same, the massacre would see interests reinterpreted in more principled terms, leading to intervention.

From a methodological perspective, tracing the discursive process within these presidential administrations requires a 'structured, focused' interpretive approach (George \& Bennett, 2005) to examine tensions between these principled and cognitive ideas. With regards to principled types of ideas - these are expressed in rhetoric and public discourse based on narrative and memories of past events. Cognitive types of ideas, by contrast, are expressed in intellectual and institutional discourses. In terms of issue area and case selection, Bosnia - and areas concerning international security and the balance of power - represents a 'least likely' (Eckstein, 1975) case for military intervention given the fears of quagmire and professed lack of strategic interests. Significantly, variation in such areas is considered less likely if the rationalist assumption, that agents' use information efficiently, is to be adopted. Thus, applying a discursive institutionalist theoretical approach to this case highlights the endogenous dynamics which give rise to varying interpretations. Discursive 
institutionalism has typically not been applied to security matters in international politics, predominantly being applied to studies in International Political Economy.

While I make no claims that either cognitive or principled ideas are more or less likely to lead to intervention - the varying reliance by agents on these different types of ideas does help to explain variation in foreign policy decisions to use force. In the following section, I apply this framework to provide greater insights into the variation in the US's Bosnia policy given the otherwise relative stability in the material and ideational foundations of state interests.

\section{Bosnia - 'a problem from hell'}

\section{Background}

Prior to its disintegration, Yugoslavia had been composed of six republics. In June 1991, however, in response to Serbian President Slobodan Milosevic's increasingly nationalist effort to expand Serbian dominance (Albright \& Woodward, 2018, p. 98), Slovenia and Croatia seceded from the Republic (Power, 2003, p. 247). However, given the high population of Serbs and Milosevic's ability to appeal to ethnic fears and resentments (Albright 2003, p. 179), Croatia was unable to secede without bloodshed. Over the following seven months, more than 10,000 died in a war against the Yugoslav National Army (JNA), with an additional 700,000 people displaced (Power, 2003, p. 247).

In March 1992, having consulted with European and Western diplomats, leaders of the Bosnian Republic chose to hold a referendum to decide whether or not Bosnia should secede from Yugoslavia. The vote to secede won with an overwhelming 99.4\% in favour (Power, 2003, p. 248). However, members of the Serbian leadership had encouraged many Bosnian Serbs to boycott the referendum and (Rogel, 1998, p. 31), with Milosevic backing them, declared a separate Bosnian Serb state within the borders of Bosnia. Supporting their claim were members of the Serb-majority JNA, along with local Bosnian Serb forces, which constituted a force of around 80,000. As had happened in Croatia, violence began to rise. Soon after, Serb forces began destroying cultural and religious sites and compiled lists of Muslim and Croat intellectuals and professionals. Many were savagely beaten; others were executed (Power, 2003, p. 249).

In an effort to limit the escalation of violence in the region, the UN Security Council had unanimously adopted resolution 713 on 25 September 1991, which stated, 'States shall, for the purposes of establishing peace and stability in Yugoslavia, immediately implement a general and complete embargo on all deliveries of weapons and military equipment' (UNSC, 1991). However, the resolution would have the unintended consequence of leaving Bosnians with no capacity to acquire weapons when they seceded in 1992 . The result was a significant imbalance between the resources of the Bosnian Muslims and the well-armed JNA-backed forces of Milosevic. They were left virtually defenceless. This set the stage for violence to spread, rapidly developing into one of the most horrific instances of ethnic cleansing of the twentieth century.

\section{Bush's cognitive repression - 'we don't have a dog in the fight'}

In February 1991, Deputy Secretary of State, Lawrence Eagleburger travelled to the region to warn Milosevic against the use of violence. Like many in the administration, Eagleburger 
had thought that warnings of impending bloodshed were symptomatic of typical bureaucratic exaggeration. Yet, on his return, having witnessed Milosevic's willingness to use force, he remarked 'It is going to be bloody as hell' (Power, 2003, p. 253). Despite knowledge of the potential scale of the impending conflict, there was little division within the administration that direct US engagement - especially putting boots on the ground was not an option. As Samantha Power observes,

The war's viciousness had been forecast so regularly and so vividly as to desensitize US officials. By the time the bloodshed began, US officials were almost too prepared: They had been reading warning cables for so long that nothing could surprise them. (Power, 2003, p. 252)

Few within the senior ranks of the administration saw involvement in the Bosnian conflict as vital to US interests. For instance, Brent Scowcroft, Bush's National Security Advisor, was aware of the potential for violence between ethnic groups, noting it was 'A very tough, nasty neighbourhood' (Halberstam, 2001, p. 42). ${ }^{6}$ James Baker argued that the US did not 'have a dog in this fight' (Power, 2003, p. 267). Dick Cheney, insisted during an interview with the New York Times that 'This is an internal civil war ... Much as I'm appalled by the loss of life we see in Yugoslavia, that does not automatically mean that United States forces ought to be involved on the ground in Yugoslavia, trying to end that conflict' (Schmitt, 1992). These cognitive ideas became established in coordinative policy spheres prior to the outbreak of much violence and would prove difficult to overcome. Seeking to avoid engagement in the conflict, Bush announced in April 1992 that the US would formally recognise former Yugoslav Republics. Further, Bush stated that the US 'will begin immediate consultations to establish full diplomatic relations' (Bush, 1992). In doing so, Bush had hoped that this would send a signal that the US - and the international community more broadly - recognised Bosnia and other Republics as legitimate states. However, Bush's rhetoric did little to dissuade Milsovic. Shortly after, Milosevic's forces initiated a sustained siege against the Bosnia capital, Sarajevo. Sarajevo was soon surrounded by Serbian forces, who began an all-out onslaught on the defenceless city. By one account - for every shot fired by the virtually unarmed Bosnia's, Serbian forces fired nearly 180 shots (Halberstam, 2001, p. 122). Given Sarajevo's geography, occupants of the town had no escape. It was like shooting fish in a barrel, as the main street through the city of Sarajevo became referred to as 'Sniper Alley' (Halberstam, 2001, pp. 122-123). As the conflict continued to unfold - tensions between the desire to uphold and lead the way on human rights and atrocity prevention, and efforts to limit military interventions to instances of narrowly defined geostrategic interests, began to grow.

By mid-1992, images of Serbian death camps had begun to emerge enabling many US newspapers to draw parallels with the Holocaust. Emphasising this parallel, an editorial in the Chicago Tribune stated: 'The ghost of WWII genocide is abroad in Bosnia' (What goes on in Bosnia's camps?, 1992). Similarly, The New York Times editorial stated: 'The chilling reports from Bosnia evoke this century's greatest nightmare, Hitler's genocide' (Milosevic Isn't Hitler, But ..., 1992). The editorial drew parallels of the West's push for a political solution to Neville Chamberlain's appeasement of Hitler. Likewise, an editorial in the New Republic stated; 'There have been too many platitudes about the responsibility of 'all factions' for the war. This lazy language is an escape hatch through which outside powers flee their responsibilities' (Rescue Bosnia, 1992). However, even in the face of sustained 
criticism, the administration repressed these principled, communicative appeals for intervention, justifying inaction on the basis that conflict was fuelled by ancient ethnic hatreds. This was made possible by Bush and senior administration officials falling back on the institutionalised Powell-Weinberger doctrine, arguing; 'Before I'd commit forces to battle, I want to know what's the beginning, what's the objective, how's the objective going to be achieved and what's the end' (Bush quoted in Power, 2003, p. 273). As such, these principled communicative appeals failed to displace entrenched cognitive interpretations of interests which acted as powerful weapons bolstering cognitively-laden arguments developed in the coordinative policy sphere.

Bush himself had serious issues trying to understand the complexities of the Bosnian conflict. Brent Scowcroft recalled that on several occasions at the beginning of briefings, Bush would begin by saying 'Now, tell me again what this is all about' (Halberstam, 2001, p. 44). Scowcroft noted that Bush would often lose focus due to the overly complex content of the briefings. Given the complex history of deep ethnic rivalries and divisions driving the conflict, they believed that there was little chance the American public would understand them, let alone maintain support for intervention if they saw American troops coming home in body bags (Halberstam, 2001, p. 44).

To quell growing criticism of the administration's Bosnia policy, Powell penned an oped in the New York Times which vehemently argued against deploying troops when the goals were 'unclear' in a conflict 'with deep ethnic and religious roots that go back a thousand years' (Powell, 1992). Furthermore, acting Secretary of State, Lawrence Eagleburger, was quoted in the Financial Times as stating that the conflict in Bosnia is 'a civil war based in 500-1000 years of history' (Eagleberger quoted in the Financial Times, 1992). Across these statements, it was clear that those within the administration increasingly saw Bosnia as a complex, irreconcilable conflict that would only lead US forces into a quagmire should they become involved. It did not meet the narrow parameters outlined by the now almost biblical Powell Doctrine established within the coordinative policy sphere.

The Bush administration held little concern for the regional balance of power. And, as Powell would make very clear, there were no viable military options that fell within the restrictive criteria of the Powell doctrine to satisfy those in the coordinative policy sphere. On this basis, the administration saw the prospect of intervention as posing a high risk with no strategic benefit. Given the overwhelming will to avoid becoming entrenched in an enduring civil war, news coming out of Bosnia and emotional calls for action were unable to overcome the institutional barricades the administration had in place. In this way, cognitive repression by the Bush administration would see balance of power concerns, and understandings of 'what works' (Widmaier, 2016, p. 16) overcame more principled interpretations of the crisis.

\section{Cognitive repression in the Clinton administration}

These insulated institutional preferences persisted even as Bush left office. For the incoming Clinton administration, foreign policy was not a priority (Drew, 1995, p. 144). ${ }^{7}$ As a former small-state Governor, Clinton had relatively little experience when it came to matters of foreign policy. This lack of foreign policy experience coupled with general disorganisation in foreign policy matters gave Powell tremendous capacity to influence and limit the scope for intervention. Powell likened Clinton's foreign policy meetings to 
'graduate-student bull sessions' in which discussions were unstructured and had a tendency to meander (Powell \& Persico, 1996, p. 576). However, unlike the Bush administration - the Clinton administration was generally optimistic regarding the prospect of intervention. In particular, Vice President Al Gore, UN Ambassador Madeline Albright, and National Security Advisor Anthony Lake - advanced powerful principled arguments calling for intervention. Given his success in the Persian Gulf campaign, ${ }^{8}$ Powell commanded significant influence in the coordinative policy sphere.

Perhaps the most significant variation in opinions was between Powell and Albright. Powell had attained a great level of credibility for his handling of the Gulf War crisis, and when asked about military options in Bosnia, he would put forward arguments consistent with his views regarding the need for overwhelming force, arguing that the costs of any form of military action far outweighed the benefits to America's vital security interest. Powell's position had not budged with the change of administration. As such, he vehemently opposed almost any form of intervention as 'No American President could defend to the American people the heavy sacrifice of lives it would cost to resolve this baffling conflict' (Powell \& Persico, 1996, pp. 577-578). Providing a 'presence' was not enough for Powell to support action. 'Symbols' - even moral ones - were pointless in his eyes unless there was a clear set of objectives and a reasonable chance of success. This was not the case in Bosnia according to Powell. Without a clear set of achievable objectives - Powell was dug into position. Powell's command of military aspects of the crisis had the effect of Clinton shifting from an early sense of optimism toward a position of restraint. As such, Clinton would repress more principled interpretations put forth by others in his administration.

In an effort to change US policy on Bosnia, Albright in collaboration with Anthony (Tony) Lake, the National Security Advisor, and Vice President Al Gore pushed for what they termed 'lift and strike' action (Albright, 2003, p. 181). The basic premise behind 'lift and strike' was to lift the arms embargo - which had been in place since September 1991 - on arms shipments to Sarajevo to provide Bosnians a means of self-defence, and threaten Serb forces with airstrikes to keep them at bay. This would have the effect of protecting vulnerable Bosnians without putting US troops in harm's way. Clinton initially supported the idea, sending Secretary of State, Warren Christopher to Europe to discuss the policy with the European allies. However, on the back of Powell's warnings of quagmire, Clinton's support wavered (Drew, 1995, p. 157). ${ }^{9}$ Powell's cognitively-laden argument for restraint remained too strong to be displaced by more principled types of ideas.

Following one meeting of the National Security Council, in which Powell conducted his usual in-depth analysis as to why military action in Bosnia was an impossibility, Albright remarked: 'What are you saving this superb military for, Colin, if we cannot use it?' (Albright, 2003, p. 183). Powell remarked in his memoirs that Albright's comment nearly gave him an 'aneurysm' and he felt compelled to explain to her the role of American's military (Powell \& Persico, 1996, p. 576). Despite fierce opposition from Powell, Albright remained steadfast in her belief that limited military operations could be conducted, and that Powell's opposition was a product of overlearning the lessons of Vietnam (Albright, 2003, p. 183). Within the administration, Albright was regularly the only one to stand up to Powell (Blumenthal, 2003, p. 63). Yet even Albright ceded to his authority as he would show up to meetings with maps and charts, to outline just how difficult, dangerous, and costly military action would be if the US were to have any chance of 
making a genuine impact. Thus, given this technocratic, cognitive framing, as a complex conflict, fuelled by ancient ethnic tensions - Albright, and others in the administration were unable to successfully displace this institutionalised interpretation and advance their more principled, humanitarian approach.

As a result of Powell's unrivalled authority in military matters, the new administration had been warned of the perilous conditions to which ground troops would be subjected should they be inserted into the mountainous terrain of the Balkans. Powell left the administration in September 1993 - yet even when out of office, he continued to be a vocal opponent of intervention in Bosnia describing the conflict as 'baffling' and not worth the risk (Blumenthal, 2003, p. 63). His refined, cognitive types of ideas served as powerful constraints within the Clinton administration, acting to repress principled, communicative appeals which likened violence against Bosnian civilians to the Holocaust.

\section{'What should I tell my daughter' - Srebrenica and normative displacement}

For more than two years, Clinton would continue to repress principled, communicative calls from both the public and within his administration interpreting US interests toward the Bosnia conflict through these more refined, cognitive types of ideas. However, these interpretations would be displaced in July 1995 when Srebrenica, one of eastern Bosnia's last remaining Muslim enclaves, came under siege. On July 6, General Ratko Mladic's ${ }^{10}$ forces began shelling Srebrenica, taking the town five days later. Women and children were expelled from the town, the men were slaughtered (Albright, 2003, p. 188). Between 11 and 22 July, more than 8000 Bosnian men and boys were slaughtered in a horrific act of ethnic cleansing. Following the fall of Srebrenica - French President Jacques Chirac spoke with Clinton, refreshing comparisons of the West's response to years of Serbian aggression to that of Neville Chamberlain's appeasement of Hitler. This was a cold blow from one of the US's closest allies - to be accused of impotent leadership and appeasing tyrants and mass murderers (Halberstam, 2001, p. 316). Significantly, the massacre at Srebrenica would prove to be a vital catalyst for shifting US interpretations of Bosnia toward more principled ones.

Following the slaughter, images of Bosniak victims made their way onto the front page of major newspapers throughout the United States. These images would prove particularly powerful renewing popular calls for a review of the administration's Bosnia policy. In particular, one story featured in the Washington Post described a photo of a young Bosnian woman who had committed suicide. The story opened:

The young women died with no shoes on. Sometime Thursday night she climbed a high tree near the muddy ditch where she had camped for 36 hours. Knotting a shabby floral shawl together with her belt, she secured it to a branch, ran her head of black hair through the makeshift noose and jumped... She had no relatives with her and sobbed by herself until the moment she scaled the tree. (Pomfret, 1995)

Indeed, the sight of Eastern Europeans dying, and pleading for their lives struck at the heartstrings of Americans. Particularly symbolic was Al Gore's twenty-one-year-old daughter - having seen the devastating photo of a young Bosniak woman - would question her father as to how the administration could justify doing nothing. Gore spoke to Clinton of his daughter's shock at the horrors faced by everyday people in the conflict. He urged 
Clinton that the policy of 'acquiescence' could no longer stand (Halberstam, 2001, p. 331). Two days after Srebrenica fell, the foreign policy principles met in the Oval Office. Gore spoke candidly before the other principles, 'My 21-year-old daughter asked about that picture ... What am I supposed to tell her? Why is this happening, and we're not doing anything?' (quoted in Harris, 2006, p. 196). This proved to be a pivotal moment in turning the administration's policy toward Bosnia.

The administration's polling demonstrated that Americans were against putting troops on the ground, yet images of widespread bloodshed engendered support for a far more robust use of airpower, adding influence to their principled, communicative appeals (Harris, 2006, p. 196). Responding to the massacre in Srebrenica had become a question of values. What happened in Srebrenica was not just about genocide, it was about the very fabric of the West (Harris, 2006, p. 326). Furthermore, for the first time during the Bosnian conflict, both Gore and Clinton were on the same page. Adding a to the level of urgency was the concern that Serbian forces may strike other enclaves. Zepa and Gorazde were also in danger. Defending these towns had become critical; further emphasising tensions between the success of the Powell Doctrine, which had become entrenched in virtually all considerations regarding the use of force in the coordinative policy sphere, and the restrictions it placed on agents ability to uphold their principles and do 'what's right' (Widmaier, 2016, p. 15). The massacre, along with images of murdered innocents saw normative displacement shift the interpretation of debate over Bosnia from more refined cognitive types of ideas pursued by Powell, toward much more principled interpretations of 'what's right' (Schmidt, 2008, pp. 306-309; Widmaier, 2016, p. 15). There was no fundamental change to the material or ideational foundations of state interests. Instead, the atrocities enabled greater communicative support for principled interpretations that the administration could no longer ignore.

These images would come with such an emotional charge that even more technocratic members of the administration would succumb to these principled interpretations. These included Secretary of Defence, Bill Perry, and Chairman of the Joint Chiefs of Staff, John Shalikashvili ${ }^{11}$ who were shocked by what they saw coming out of Srebrenica. Marking a significant shift, Perry began to advocate for robust airpower, 'not a bomb or two, not a pinprick, but a massive air campaign' (quoted in Harris, 2006, p. 197). Likewise, John Shalikashvili had been wary of intervening in Bosnia. Given his military background, Shalikashvili shared a common approach to matters of military engagement as his predecessor, Colin Powell. Yet, the images coming out of Srebrenica would see a softening of this approach (Harris, 2006, p. 197). However, Perry and Secretary of State, Warren Christopher would remain sceptical - to varying degrees - about intervention in the Bosnian conflict.

On top of the general change of heart from those in the administration who had initially opposed notions of intervention, Clinton came under pressure following powerful, principled, communicative appeals from the Senate and the Congress to lift the arms embargo. Senate Majority Leader, Bob Dole, pushed through legislation demanding that the US lift the arms embargo so as to allow Bosnian Muslims to defend themselves (Harris, 2006, pp. 196-197). The bill had bipartisan support, with twenty-one Senate Democrats breaking ranks with the Clinton administration, siding with forty-eight Republicans. Californian Democratic Senator, Dianne Feinstein stated: 'For me the turning point was the attack on Srebrenica, that weekend with all the missing people ... One image punched through to me: that young woman hanging from a tree. That to me said it all' (Feinstein 
quoted in Sciolino, 1995). Some of the votes represented a significant switch in position, including Georgia Democrat Senator, Sam Nunn, and Virginia Republican Senator, John Warner, both of whom had previously supported presidential prerogatives on matters of foreign policy (Sciolino, 1995).

Given these developments, Clinton came to realise that the current Bosnia policy was doing 'enormous damage to the United States and to our standing in the world. We look weak ... The only time we've made progress is when we geared up NATO to pose a real threat to the Serbs' (quoted in Harris, 2006, p. 200). In an effort to redress the issues Clinton faced in Bosnia, Lake had developed the 'Endgame Strategy' which sought to advance a strong diplomatic solution to the Bosnia conflict, backed by - not just the threat - but use of force if necessary (Harris, 2006, p. 199). Given the mounting pressure to act, Lake's proposal was well received by Clinton. The complexities of ancient ethnic rivalries that had consumed the coordinative policy sphere of the Bush administration and the early years of the Clinton administration fell away. The consequences of doing nothing became more pertinent, and the human toll more apparent. The mindset of the administration had shifted - Bosnia was now understood in a new light.

On the morning of 10 August, the Security Council gathered for a closed-door session. At the meeting, Albright - in an effort to mobilise support for the administration's renewed policy - distributed photos gathered by US intelligence agencies along with accounts from refugees from Srebrenica to tell a story of what had happened. The photos taken by US spy satellites showed approximately six hundred people standing together on a soccer field in the town of Nova Kasaba on July 13. The next photo taken on July 27 showed areas down the road where the ground had been upturned along with numerous sets of vehicle tracks (Albright, 2003, p. 189). These were mass graves concealing the bodies of the hundreds of people seen weeks earlier. Before the Security Council, Albright declared 'The Bosnian Serbs have executed, beaten, and raped people who were defenceless. They have carried out a calculated plan of atrocities far from a battlefield and with the direct involvement of high-level Bosnian Serb Army officials' (UNSC, 1995). Albright's photographic evidence was supported further by two Bosnian refugees who had survived the massacre by hiding under the bodies of their fallen friends. Other eyewitnesses recounted similar stories:

They took us off a truck and led us out into some kind of meadow. People started taking off blindfolds and yelling in fear because the meadow was littered with corpses. I was put in the front row, but I fell over to the left before the first shots were fired so that bodies fell on top of me ... After a bulldozer driver walked away, I crawled over the dead bodies and into the forest. (Power, 2003, pp. 415-416)

By mid-August, the US had sent a team of negotiators to the region to set out terms of an agreement to see Bosnia remain as a sovereign democratic state. However, on the day that American negotiators returned from Europe on 28 August, Serb forces chose once again to bomb civilian targets. The strikes killed thirty-seven civilians and left dozens more wounded (Albright, 2003, p. 191). This would prove to be the first test of the administration's new Bosnia policy. Two days later, sixty aircraft from bases in Italy, and the USS Theodore conducted comprehensive airstrikes on Serb positions around Sarajevo, amounting to the largest NATO military operation to date (Albright, 2003, p. 241). The decisive nature of these strikes demonstrated that existing cognitive interpretations of US interests 
in the coordinative policy sphere toward the Bosnian conflict had been displaced as principled, communicative appeals gained momentum and could no longer be ignored. It seemed after years of restraint, the administration was seeking to exercise a greater degree of leadership as Clinton came to realise that the integrity of not only the administration but of the United States as global leaders came into question if they were not able to hold aggressors of such atrocities to account.

The bombing proved effective taking out General Mladic's communications centre, neutralising the Serbs ability to move forces quickly. Overnight the Serbs had become blind and deaf on the battlefield (Halberstam, 2001, pp. 348-349). Within weeks Serb forces had largely lost control of territory they had formally. The administration ceased on this moment of shock to Serbia's forces, sending US negotiators to the region to discuss terms for peace in an effort to bring the conflict to an end. On 5 October, they achieved an agreement for a nation-wide ceasefire. The final agreement would be made in November during peace talks in Dayton, Ohio (Albright, 2003, p. 192). By 21 November 1995, the Bosnian war had come to a timely end (Albright, 2003, p. 193). Getting the parties to the table proved to vindicate several principles obscured by early successes of the Powell Doctrine. First, American leadership was critical in leading 'the forces of peace and freedom' which were not only necessary in ending the Bosnian war, but would also serve to advance 'strategic interests' and 'fundamental values' (Clinton, 2004, p. 685). ${ }^{12}$ Additionally, it demonstrated that limited force - even just the use of airstrikes - could make a decisive difference (Albright, 2003, p. 193). It was only through a prolonged crisis in global leadership and repeated failures to prevent mass atrocities that a shift from cognitive interpretations to more principled ones, necessary to motivate the use of force, was achieved.

\section{Conclusion}

This analysis has important implications for theoretical debates, and understanding variation in foreign policy decision-making. Concerning theoretical IR debates, this analysis challenges realist, constructivist, and historical institutionalist theories which suggest to varying degrees for material or ideational reasons - that exogenous shocks bring about new sets of interests and ideas. More formally, I have highlighted how these scholars have overstated the capacity of agents to interpret interests consistently. Furthermore, they hold the implied assumption that agents use information efficiently, thus, overrating interpretive efficiency. Such a shortcoming has left these approaches unable to explain variation in foreign policy choice where the material or ideational bases of state interests remain formally the same.

To redress this issue, I have advanced a discursive institutionalist analysis to highlight how agents come to rely on different types of socially constructed principled or cognitive ideas. In doing so, I have provided a means of analysing endogenous sources of variation in US foreign policy interests, thus, explaining the shift from restraint to intervention even as the material and ideational foundations of state interests remained formally the same. In this way, I show how cognitive ideas, justified in the coordinative policy sphere, seeking to maintain the balance of power and avoid quagmire led to cognitive repression as the Bush administration came to repress principled, communicative appeals. As such, even as members of Congress called for intervention and public calls for action likened 
ethnic cleansing in Bosnia to the Holocaust, technocrats including Powell and Scowcroft (and President Bush who agreed with their assessments) emphasised the need for restraint. In doing so, they would point to Vietnam as a justification for caution in the use of military force. This proved a powerful weapon for repressing communicative appeals. Significantly, this repression remained even with a change of administration, which saw the rise of more interventionist agents including Albright, Gore, and Lake. As long as the US's vital security interests were not at stake, the US 'had no dog in the fight' (Power, 2003, p. 253).

Following the massacre at Srebrenica in 1995, in which 8000 Bosnia men and boys were systematically slaughtered, memories of the Holocaust would re-emerge as normative displacement would see a more principled interpretation of interests as the 'psychological balance' shift and broader communicative appeals could no longer be ignored in the coordinative policy sphere (Albright, 2003, p. 191). Images of dead and dying Bosnian Muslims would shock even the most cautious in the administration. Such images would serve to displace more refined, cognitively-laden, balance of power interpretations that the US didn't 'have a dog in the fight' (Power, 2003, p. 267) toward a more value-laden interpretation regarding 'what's right' (Widmaier, 2016, p. 15) as it became clear that existing approaches to Bosnia had become a 'cancer' (Woodward, 1996, p. 253) on US foreign policy, affecting the administration's capacity to act in other areas. In this way, institutional technocratic efforts would yield as principled interpretations dominated discourse within the Clinton administration.

This approach has highlighted an important opening for further use of discursive institutionalism in understanding foreign policy decision-making. Significantly, there is likely scope for a broader application in security areas of IR as well. Discursive institutionalism has the potential to provide valuable insights into foreign policy analysis that existing perspectives have tended to overlook on account of their implied assumptions that agents use information efficiently. Specifically, as demonstrated through the analysis of deliberations over US policy on Bosnia, discursive institutionalist approaches allow greater capacity to examine endogenous factors that yield variation in state interests.

\section{Notes}

1. Schmidt (2008) distinguishes between 'causal' and 'normative types of ideas. 'Causal' ideas speak to agents 'interest-based logic' providing instructions on 'what is and what to do' (2008, pp. 306-308).

2. On 'repression' and its forms see Kaplan (1957) and Kahneman (2012).

3. On 'uncertainty' and its forms, see Best (2008, p. 359, 2012, p. 677). On radical uncertainty, see Knight (1946).

4. Schmidt (2008, p. 307) emphasises the point that there is a 'built-in bias that seems to assume that 'good' ideas - meaning those that appear more relevant to the problem at hand, more adequate to the task, and more appropriate to the needs of society - succeed while 'bad' ideas fail'.

5. The Powell Doctrine (sometimes referred to as the Weinberger doctrine) is an approach to foreign policy which calls for restraint in the use of military force in foreign policy unless it is necessary for the protection of vital national security interests.

6. Eagleburger suggested in an interview with David Halberstam that complaints from junior administration officials - that their resistance to more decisive action may be driven by their views of what the Serbs might do if confronted with military force. 
7. Clinton was the first US President since Harry Truman not to have a regularly scheduled meeting with his foreign policy team.

8. The 'Persian Gulf campaign' refers to the first US war against Iraq between 1990 and 1991.

9. To get Clinton to see his point of view, Powell recommended Clinton read Robert Kaplan's Balkan Ghosts (1993), which detailed a long history of deep-seated, ancient ethnic tensions in the Balkans.

10. General Ratko Mladic was one of the key commanders responsible for ordering Serb forces to overrun Srebrenica in 1995. He was also a key figure during earlier peace negotiations in 1993.

11. General John Shlikashvili became the Chairman of the Joint Chiefs of Staff following the end of Powell's term in October 1993. Like Powell, Shlikashvili was cautious about the use of military though he is described as being more approachable than Powell by civilian members of the administration.

12. Clinton's reference to 'strategic interests' and 'fundamental values' closely align with Schmidt's (2008) causal and normative types of ideas.

\section{Acknowledgements}

I would like to thank Wesley Widmaier, Sara Davies, and Caitlin Mollica for their helpful comments and feedback. I would also like to than the two anonymous reviewers for their time and insights. Any remaining errors are my own.

\section{Disclosure statement}

No potential conflict of interest was reported by the author.

\section{Notes on contributor}

Morgan completed his Ph.D. in 2019. He currently works at Griffith University's School of Government and International Relations as a sessional instructor. His research interests include American Foreign Policy and International Relations theory.

\section{ORCID}

Morgan Thomas Rees (D) http://orcid.org/0000-0002-2338-5615

\section{References}

Albright, M. (2003 [2013]). Madam secretary: A memoir. New York: Harper Perennial.

Albright, M., \& Woodward, B. (2018). Fascism: A warning. London: William Collins.

Barnett, M. N., \& Finnemore, M. (1999). The politics, power, and pathologies of international organizations. International Organization, 53(4), 699-732.

Bell, S. (2017). Historical institutionalism and new dimensions of agency: Bankers, institutions and the 2008 financial crisis. Political Studies, 65(3), 724-739.

Best, J. (2008). Ambiguity, uncertainty, and risk: Rethinking indeterminacy. International Political Sociology, 2(4), 355-374.

Best, J. (2012). Ambiguity and uncertainty in international organizations: A history of debating IMF conditionality. International Studies Quarterly, 56(1), 674-688.

Blumenthal, B. (2003). The Clinton wars. New York: Farrar, Straus and Giroux.

Blyth, M. (2001). The transformation of the Swedish model: Economic ideas, distributional conflict, and institutional change. World Politics, 54(1), 1-26. 
Blyth, M. (2002). Great transformations: Economic ideas and institutional change in the twentieth century. Cambridge: Cambridge University Press.

Bush, G. H. W. (1992, April 7). Statement on United States recognition of the former Yugoslav republics. Retrieved from http://www.presidency.ucsb.edu/ws/index.php?pid=20810\&st=Bosnia\&st1=

Campbell, J. L., \& Pedersen, O. K. (2010). Knowledge regimes and comparative political economy. In D. Beland \& R. H. Cox (Eds.), Ideas and politics in social science research (pp. 167-190). Oxford: Oxford University Press.

Capoccia, G., \& Kelemen, R. D. (2007). The study of critical junctures: Theory, narrative, and counterfactuals in historical institutionalism. World Politics, 59(3), 341-369.

Carstensen, M. B., \& Schmidt, V. A. (2016). Power through, over and in ideas: Conceptualizing ideational power in discursive institutionalism. Journal of European Public Policy, 23(2), 318-337.

Clinton, B. (2004). My life. London: Arrow Books.

Drew, E. (1995). On the edge: The Clinton presidency. New York: Touchstone.

Dueck, C. (1996). Reluctant crusaders: Power, culture, and change in American grand strategy. Princeton, NJ: Princeton University Press.

Eckstein, H. (1975). Case study and theory in political science. In F. I. Greensteinand \& N. W. Polsby (Eds.), Handbook of political science (pp. 79-138). Reading, MA: Addison-Wesley.

Fearon, J., \& Wendt, A. (2002). Rationalism v. constructivism: A skeptical view. In W. Carlsnaes, T. Risse, \& B. A. Simmons (Eds.), Handbook of international relations (pp. 52-72). London: SAGE Publications.

Financial Times. (1992, August 10). UN may back force in Bosnia.

Finnemore, M., \& Sikkink, K. (1998). International norm dynamics and political change. International Organization, 52(4), 887-917.

Fioretos, O. (2011). Historical institutionalism in international relations. International Organization, 65 (2), 367-399.

George, A., \& Bennett, A. (2005). Case studies and theory development in the social sciences. Cambridge: MIT Press.

Gilpin, R. (1981). War and change in world politics. Cambridge: Cambridge University Press.

Haas, P. M. (1992). Introduction: Epistemic communities and international policy coordination. International Organization, 46(1), 1-35.

Halberstam, D. (2001). War in a time of peace: Bush, Clinton, and the generals. New York: Simon \& Schuster.

Harris, J. F. (2006). The survivor: Bill Clinton in the White House. New York: Random House.

Hay, C. (1996). Narrating crisis: The discursive construction of the 'winter of discontent'. Sociology, 30 (2), 253-277.

Kahneman, D. (2012). Thinking fast and slow. London: Random House.

Kaplan, M. (1957). System and process in international relations. New York: John Wiley.

Kaplan, R. D. (1993). Balkan ghosts: A journey through history (1st ed.). New York: St. Martin's Press.

Kissinger, H. (1994). Diplomacy. New York: Simon \& Schuster.

Knight, F. H. (1946). Risk, uncertainty and profit. Boston, MA: Houghton Mifflin Company.

Mahoney, J., \& Thelen, K. A. (2010). Theory of gradual institutional change. In J. Mahoney \& K. Thelen (Eds.), Explaining institutional change: Ambiguity, agency, and power (pp. 1-37). Cambridge: Cambridge University Press.

March, J. G., \& Olsen, J. P. (1998). The institutional dynamics of international political orders. International Organization, 52(4), 943-969.

Milosevic Isn't Hitler, But... . (1992, August 4). The New York Times. Retrieved from https://www. nytimes.com/1992/08/04/opinion/milosevic-isn-t-hitler-but.html

Morgenthau, H. (1948). Politics among nations: The struggle for power and peace. New York: McGraw-Hill. Onuf, N. (1989). World of our making. Columbia: University of South Carolina Press.

Pierson, P. (2004). Politics in time: History, institutions and social analysis. Princeton: Princeton University Press.

Pomfret, P. (1995, July 15). 'We count for nothing'; Srebrenica refugees unwelcome in Tuzla. The Washington Post (Pre-1997 Fulltext). Retrieved from http://search.proquest.com.libraryproxy. griffith.edu.au/docview/307889116?accountid=14543 
Powell, C. (1992, October 8). Why generals get nervous. The New York Times (online). Retrieved from https://www.nytimes.com/1992/10/08/opinion/why-generals-get-nervous.html

Powell, C., \& Persico, J. E. (1996). My American journey. New York: Ballantine Books.

Power, S. (2003). "A problem from hell": America and the age of genocide. New York: Harper Perennial.

Rescue Bosnia. (1992, August 17). The New Republic. Retrieved from https://search-proquest-com. libraryproxy.griffith.edu.au/docview/212883537/fulltextPDF/C860D4C4238B462BPQ/1? accountid $=14543$

Rogel, C. (1998). The breakup of Yugoslavia and the war in Bosnia. Westport: Greenwood Press.

Rose, G. (1998). Review: Neoclassical realism and theories of foreign policy. World Politics, 51(1), $144-172$.

Ross, A. A. G. (2006). Coming in from the cold: Constructivism and emotions. European Journal of International Relations, 12(2), 197-222.

Schmidt, V. A. (2006). Democracy in Europe: The EU and national polities (1st ed.). Oxford: Oxford University Press.

Schmidt, V. A. (2008). Discursive institutionalism: The explanatory power of ideas and discourse. Annual Review of Political Science, 11, 303-326.

Schmidt, V. A. (2010). Taking ideas and discourse seriously: Explaining change through discursive institutionalism as the fourth 'new institutionalism'. European Political Science Review, 2(1), 1-25.

Schmidt, V. A. (2014). Speaking to the markets or speaking to the people? A discursive institutionalist analysis of the EU's sovereign debt crisis. The British Journal of Politics and International Relations, $16(2), 188-209$.

Schmitt, E. (1992, July 1). Cheney talks of an air role in Bosnia. The New York Times (online). Retrieved from https://www.nytimes.com/1992/07/01/world/cheney-talks-of-an-air-role-in-bosnia.html

Schweller, R. L. (1998). Deadly imbalances: Tripolarity and Hitler's strategy of world conquest. New York: Columbia University Press.

Sciolino, E. (1995, July 28). Conflict in the Balkans: The politics; Senate vote to end embargo may prove a pyrrhic victory. New York Times (online). Retrieved from http://www.nytimes.com/1995/ 07/28/world/conflict-balkans-politics-senate-vote-end-embargo-may-prove-pyrrhic-victory.html? pagewanted=all

United Nations Security Council. (1991). Resolution 713. 25 September, S/Res/713.

United Nations Security Council. (1995, August 10). 3564th Meeting. S/PV.3564.

Waltz, K. N. (1979). Theory of international politics. New York: Random House.

Wendt, A. (1999). Social theory of international politics. Cambridge: Cambridge University Press.

What goes on in Bosnia's camps? (1992, August 6). Chicago Tribune (Pre-1997 Fulltext). Retrieved from http://search.proquest.com.libraryproxy.griffith.edu.au/docview/283297626?accountid=14543

Widmaier, W. W. (2015). Presidential rhetoric from Wilson to Obama: Constructing crises fast and slow. Oxon: Routledge.

Widmaier, W. W. (2016). Economic ideas in political time. New York: Cambridge University Press.

Woodward, B. (1996). The choice: How Clinton won. New York: Touchstone. 